\title{
Eckhard Cloete Die dag toe James Joyce ...
}

Pa kom by die huis met'n euforiese glimlag op sy gesig.

"Christiaantjie", sê hy en vryf sy hande teenmekaar soos'n stout skoolseun," jy't mos eenkeer daai oulike gedig oor James Joyce geskryf, nie waar nie?"

Sy oë trek skrefies. Ek kyk by die venster uit.

"Ag, toe nou Christiaantjie, is dit nodig om altyd moeilik te wees? Hy's hier, my magtig. In Pretoria! Wat sê jy daarvan? In die Jakarandastad! Vanmiddag vieruur by Steers. Dis'n gulde geleentheid. Jy moet tog die geleenthede benut, my seun."

"O, okay."

"O!!? Is dit is wat jy te sê het as die grootste Amerikaanse skrywer sedert Wilbur Smith in jou eie stad sy nuwe boek kom bekend stel?"

"Ek weet nie of dit dieselfde ou is nie, Pa."

“Wat meen jy jy weet nie of dit hy is nie. Dis hy. Daar's net een, almal wat'n boek kan optel en lees weet daar's net een soos James Joyce. Moenounie begin met jou postmoderne onsin nie..."

"Hans!" waarsku Ma, "los die kind uit. Jou pa het jou nie gedwing om na Shakespeare te luister toe hy in Bronkhorstspruit was nie. Buitendien, watter jongmens wil nou na'n kookboekbekendstelling toe gaan?"

"Magtig, Martha, ek vra hom nie om na die pous te gaan luister nie. Hy hou van Joyce. Dis een van sy rolmodelle. Hy kan nie wil staan en skrywer word as hy is nie eers bereid is om 'n paar kilometer na die mall te ry om te hoor wat het James Joyce te sê nie. Ek ry kwart oor drie, Christaan. Die mense gaan tou staan. Dis nie aldag dat ons geseën word met die teenwoordigheid van grootsheid nie."

Dis nou al twee-en-'n-half jaar vandat ek besluit het om terug na my ouerhuis te trek na my ekskursie in die buitewêreld. Dinge lyk altyd meer glansryk as jy dit nog nie self evaar het nie. Nie dat ek nou nie juis 
'n sukses in die oë van die samelewing behaal het nie, inteendeel: ek het taamlik goed gevaar in die tradisionele sin van die woord. Dis net: hoe sê mens iets met' $n$ reguit gesig as jy voor jou siel weet jy't nie'n clue waarvan jy praat nie?

Goed, ek erken, dis nie te moeilik om die meeste armsaliges om die bos te lei met' $n$ esoteriese term hier en ' $n$ paradoks daar nie. Maar' $n$ mens wil tog jou gewete ook kan sus. Dis hierdie netelige kwessie wat my laat besluit het om na slegs vier jaar in die akademiese dieptes van die geesteswetenskappe op'n eerbare wyse my swaard neer te lê. Ydelheid en selfrespek mag dalk bloedverwant wees, maar laasgenoemde deug nog wanneer die Narcissus se poel lankal opgedroog het. En Suid-Afrika is'n warm plek.

Na my tweede navorsingsessay ("'n Poststrukturalistiese analise van die binêre spanninge in kontemporêre toiletpapiervervaardiging: ' $n$ semiotiese dekonstruksie binne die genderdiskoers") voltooi is, het ek besluit om, anders as Don Quixote en so baie sportmanne en politici, eerder die arena te verlaat voordat ek belaglik raak.

My ouers was uiteraard effens uit die veld geslaan en selfs ' $n$ bietjie teleurgesteld (ek vermoed my pa het heimlik gehoop ek eindig, soos hy, in'n tersiêre inrigting; my ma het nog altyd die ideaal gekoester dat ek die gewone mense tot geestelike helderheid sou oorhaal vanuit die preekstoel). Nietemin het hulle hul verlore seun met ope arms in die veilige (en somtyds verstikkende) warmte van die ouerhuis teruggeneem.

Omstreeks vyf-en-twintig minute oor vier het die mense begin ongeduldig raak. Opmerkings soos "wie dink hy is hy in elk geval?" en "net oor hy kamstig'n kookboek kan skryf, beteken nie hy kan ons tyd kom staan en fokken mors nie", en nog'n paar krasser opmerkings het mildelik vanuit die skare begin vloei.

“Druk jou kookboek in jou hol op, James Joyce!" het 'n middeljarige man met'n olierige snor en'n Fila-sweetpakbroek opgemerk voor hy sy weg tussen die moerige mense oopgebaan het en in die games arcade verdwyn het.

"Ja-nee, 'it help veel jy kan 'spots of time' waardeer as jy nie eers 'slots of time' kan respekteer nie," het 'n ouerige dame langs my bygevoeg.

Maar toe James Joyce by die kombuisdeur van Steers inkom en Hom agter die toonbank stasioneer, is al die gemompel eensklaps vervang met'n paar sekondes absolute stilte voor' $n$ luide toejuiging losgebars 
het. Krete soos "Heil Dedalus" en "Lank lewe die modernisme" het soos vanuit een mond uit die waarderende gepeupel losgebars.

$\mathrm{Na}$ 'n kort toespraak deur die voorsitter van die kookboekpublikasiekomitee, wat' $n$ kort voorlesing uit die hoofstuk getiteld "Hamburgers vir die huisvrou in agt-en-'n-half maklike stappe" ingesluit het en afgesluit is met ' $n$ vergelyking tussen belangrike kookboeke en toiletpapier (albei onweglaatbaar), is die mikrofoon sonder verdere vertraging aan James Joyce oorhandig.

"But I will tell you also what I do not fear", het Hy van agter die toonbank, met'n swaar Amerikaanse aksent begin: "I do not fear to be alone or to be spurned for another or to leave whatever I have to leave. And I am not afraid" (en hy tel sy nuwe kookboek op) "to make a mistake," (en swaai dit triomfantelik in die lug) "even a great mistake, a lifelong mistake," (asems word ingetrek; doodse stilte) "and perhaps as long as eternity too." (Oorverdowende gejuig.)

Ek het Hom by Steers se agterdeur ingewag. Hy het my aanvanklik nie gewaar nie en was besig om 'n (waarskynlik komplimentêre) R2,99cone te lek.

"Verskoon tog ..." Hy het geskrik, maar vinnig reageer (asof hy verwag het dat iemand hom op'n dag sou voorlê) en my aan die kraag beetgekry en teen die muur vasgedruk.

"Ek het gewonder of ... sien, ek skryf self ..."

Hy het my vir'n oomblik stip dopgehou en toe geleidelik Sy greep verslap.'n Stukkie roomys het aan Sy snorretjie vasgekleef.

"What I mean, Sir, is that I like to be a great writer myself one d..."

"Ja-ja, ek verstaan jou."

Hy het my aangekyk, soos'n vader vir sy adolessente seun sou kyk, en toe, ek verbeel my dit was met genoegdoening en 'n momentele skalkse glimlaggie onder die stuk roomys: "Only one way to go, kid. Wat van sado-masogistiese hygliteratuur met bejaarde hoofkarakters?" (knipoog) "Real big gap in the market, kid." 